\title{
Seasonal shift in the foraging niche of Atlantic puffins Fratercula arctica revealed by stable isotope $\left(\delta^{15} \mathrm{~N}\right.$ and $\left.\delta^{13} \mathrm{C}\right)$ analyses
}

\author{
April Hedd ${ }^{1, *}$, David A. Fifield ${ }^{1,2}$, Chantelle M. Burke ${ }^{1}$, William A. Montevecchi ${ }^{1}$, \\ Laura McFarlane Tranquilla ${ }^{1}$, Paul M. Regular ${ }^{1}$, Alejandro D. Buren ${ }^{1}$, \\ Gregory J. Robertson ${ }^{3}$
}

${ }^{1}$ Cognitive and Behavioural Ecology, Psychology Department, Memorial University, St. John's, Newfoundland A1C 3X9, Canada ${ }^{2}$ Canadian Wildlife Service and ${ }^{3}$ Science and Technology Section, Environment Canada, 6 Bruce St., Mount Pearl, Newfoundland A1N 4T3, Canada

\begin{abstract}
We measured tissue stable nitrogen $\left(\delta^{15} \mathrm{~N}\right)$ and carbon $\left(\delta^{13} \mathrm{C}\right)$ values to investigate the extent of seasonal and age-related variation in the foraging ecology of Atlantic puffins. For adults, there was considerable seasonal variation in the foraging niche. A generalized, lower trophic level (TL) diet during the winter moult was replaced by a highly specialized, higher TL diet during summer when birds were rearing chicks. The seasonal $\delta^{15} \mathrm{~N}$ enrichment of $2.36 \%$ is consistent with an increase of $0.65 \mathrm{TL}$. Output from a 2 -source single isotope $\left(\delta^{15} \mathrm{~N}\right)$ mixing model suggested that adult diets were composed largely of zooplankton during winter with a switch to capelin (or other higher TL prey) in summer. A concurrent decrease in $\delta^{15} \mathrm{~N}$ variability suggests that adult diets are more varied in winter. Trophic position of first-year birds was similar across summer and fall, as they went from being provisioned by parents at the colony to feeding independently. Both isotope mixing model and stomach contents analysis suggested that first-year birds relied largely $(>85 \%)$ on capelin (or other higher TL fish) in fall. In summer, the trophic position of adults was significantly higher than that of nestlings; however, greater $\delta^{15} \mathrm{~N}$ variability suggested that nestling diet was mixed overall. Shipboard surveys indicated an offshore movement of puffins post-breeding; however, this distributional shift was not reflected in $\delta^{13} \mathrm{C}$ signatures of adults. The dietary shift and increased TL of adult Atlantic puffins from winter to summer is consistent with reports for puffin species in the Pacific, suggesting that puffins may undergo the most extensive seasonal trophic shift among the auk species.
\end{abstract}

KEY WORDS: Seasonal diet shift $\cdot$ Winter diet $\cdot$ Stable isotope analysis $\cdot \delta^{15} \mathrm{~N} \cdot \delta^{13} \mathrm{C} \cdot$ Trophic level . Fratercula arctica

Resale or republication not permitted without written consent of the publisher

\section{INTRODUCTION}

The seasonal dietary shifts of migratory animals influence populations during different times of the year and over broad spatial scales (Yerkes et al. 2008, Sorensen et al. 2009). Most dietary studies of marine birds are restricted to the breeding season when birds are accessible on land and the prey loads of provisioning adults are observed or intercepted (Robinette et al. 2007, Einoder 2009). Such colony-based information likely reflects the diets of chicks and should not necessarily be used to extrapolate adult diet (Williams et al. 2007). Also, seabird diets outside the breeding period are generally poorly known as birds disperse over large oceanic areas after leaving the colony (e.g. Gaston \& Jones 1998).

Atlantic puffins Fratercula arctica are medium-sized ( 400 to $500 \mathrm{~g}$ ) pursuit-diving auks with an estimated North American breeding population of 350000 to 400000 pairs (Lowther et al. 2002). Chick diets have 
been well studied throughout their range and exhibit variation that likely reflects prey diversity across oceanographic regions (Harris 1984, Bradstreet \& Brown 1985, Anker-Nilssen 1987). By contrast, the diet of adults is poorly known during and outside the breeding season (Lowther et al. 2002). In the Northwest Atlantic, puffins have long been considered to rely on mature fish to rear their offspring (Bradstreet \& Brown 1985, Piatt 1987, Nettleship 1991), but the high degree of dietary plasticity recently reported (Rodway \& Montevecchi 1996, Baillie \& Jones 2004, Burke \& Montevecchi 2008) suggests that lower trophic level (TL) prey, including larval fishes and invertebrates, may play a greater role than previously thought. The only previous information on adult diet originates from the 1980s, when chick-rearing puffins at Gull Island, Witless Bay, Newfoundland, relied almost exclusively on fish for self-feeding (Piatt 1987). At that time, the primary difference between adult and offspring diet was that adults consumed more Atlantic cod Gadus morhua and sandlance Ammodytes spp., while feeding their chicks a higher proportion of capelin Mallotus villosus.

Stable isotope ratios of nitrogen $\left(\delta^{15} \mathrm{~N}\right)$ and carbon $\left(\delta^{13} \mathrm{C}\right)$ in consumer tissues reflect those of the consumer's environment plus the food they eat; as such, their measurement can identify food web (trophic) and spatial (inshore or benthic versus offshore or pelagically linked food webs) relationships (e.g. Hobson 1993, Hobson et al. 2002, Hodum \& Hobson 2000, Barrett et al. 2007). These techniques are being increasingly used to examine seasonal shifts in trophic position of seabirds (e.g. Hedd \& Montevecchi 2006, Cherel et al. 2007, Williams et al. 2008, Davies et al. 2009) and to elucidate migration strategies and habitat preferences (foraging zones) during the non-breeding period (Cherel et al. 2000, 2006, Quillfeldt et al. 2005, Cherel \& Hobson 2007, Phillips et al. 2009).

In the present study we combined tissue stable isotope $\left(\delta^{15} \mathrm{~N}\right.$ and $\left.\delta^{13} \mathrm{C}\right)$ analysis (SIA) with stomach contents analysis and year-round vessel surveys of birds at sea to examine the extent of seasonal and age-related variation in Atlantic puffin feeding ecology. Using $\delta^{15} \mathrm{~N}$ and $\delta^{13} \mathrm{C}$ values, respectively, we contrasted the trophic position and presumed foraging habitats (inshore or benthic versus offshore or pelagic) of: (1) adults during winter (non-breeding, moulting) and summer (chickrearing); (2) adults and offspring during the summer chick-rearing period; and (3) first-year birds when being provisioned by parents at the colony and when subsequently feeding independently. In light of seasonal changes in bird distributions at sea (coastal versus offshore), we anticipated a negative relationship between $\delta^{13} \mathrm{C}$ and distance from shore (Hobson et al. 1994). Coupling SIA with traditional approaches, we provide initial insights into seasonal and age-related variation in the feeding ecology of Northwest Atlantic puffins.

\section{MATERIALS AND METHODS}

Study site, species and sample acquisition. Research was conducted at Gull Island $\left(47^{\circ} 16^{\prime} \mathrm{N}, 52^{\circ} 46^{\prime} \mathrm{W}\right)$ in the Witless Bay Seabird Ecological Reserve on the east coast of Newfoundland, Canada (Fig. 1). The reserve supports the largest known Atlantic puffin colony in North America, with 140 000 pairs breeding on Gull Island in 2003 (Robertson et al. 2004). In Newfoundland, puffins lay eggs in mid- to late May, hatching occurs throughout July and chicks fledge from midAugust to early September (Lowther et al. 2002). Between 22 and 27 July 2005, we caught 33 birds outside burrow entrances or on nesting slopes, weighed them and used brood patches and bill grooves to assess breeding status and age, respectively (Petersen 1976, Harris 1979). The following tissues were sampled for

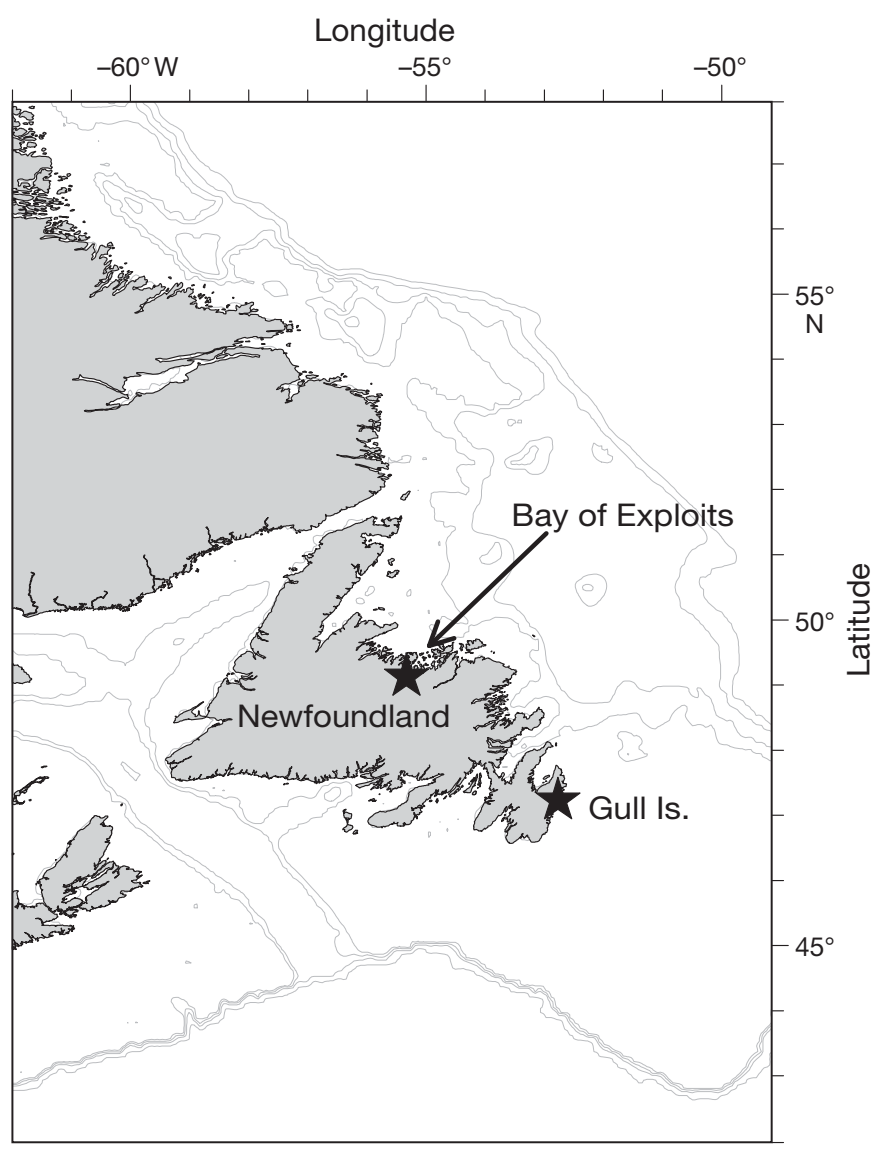

Fig. 1. Study area showing sampling locations ( $\star$ ) for Atlantic puffins (adults: Gull Island, Witless Bay; first-years: Bay of Exploits). Bathymetric contours indicate 200, 300, 500, 1000 and $2000 \mathrm{~m}$ depth 
SIA: 1 ml of blood was drawn from the brachial vein and stored in $70 \%$ isopropyl alcohol (Hobson et al. 1997), and $\sim 1 \mathrm{~cm}$ was cut from the tip of a mid-primary feather. We assumed that birds with $\geq 1.5$ bill grooves and a re-feathering brood patch were breeding adults; data from 5 birds not meeting these criteria were removed prior to analysis.

Carcasses of 11 first-year puffins shot on 23 October 2004 in the Bay of Exploits, Newfoundland (Fig. 1), were provided by the Canadian Wildlife Service, having been confiscated from hunters. We assumed that birds had fledged from colonies during the previous 6 to $8 \mathrm{wk}$ (Lowther et al. 2002). We sampled $\sim 1 \mathrm{~cm}$ of the tip of a mid-primary feather for all carcasses, and for 10 we sampled pectoral muscle and extracted the gastrointestinal (GI) tract.

The tissues chosen for SIA enabled the temporal comparisons of interest. Adult puffins in the eastern Atlantic undergo a synchronous primary moult and are flightless for a period during winter (Harris \& Yule 1977). Primary growth spans late November to mid-March, with a peak from late December to mid-February (Lowther et al. 2002). As feather keratin is metabolically inert after synthesis, its isotopic composition reflects diet at the time feathers are grown (e.g. Mizutani et al. 1992). For adults we therefore contrasted stable isotope signatures of primary feathers (reflecting diet during winter moult) with signatures from whole blood (reflecting diet during 4 to $6 \mathrm{wk}$ of the summer breeding season; Hobson \& Clark 1992, Bearhop et al. 2002). For first-year birds, we contrasted stable isotope signatures of primary feathers grown at the colony (chick summer diet) with signatures from pectoral muscle (reflecting diet over the preceding 4 to $6 \mathrm{wk}$ when juveniles were feeding independently in fall; Hobson \& Clark 1992).

SIA. Sample processing: Feathers were cleaned of surface contaminants using a 2:1 ratio solution of chloroform:methanol, air-dried under a fume hood and cut into small fragments, avoiding the quill and shaft. Blood was freeze-dried for $48 \mathrm{~h}$ and muscle was ovendried to constant mass at $60^{\circ} \mathrm{C}$. Dried samples were coarsely ground and lipids were removed using a 2:1 ratio solution of chloroform:methanol. Blood and muscles samples were powdered when re-dried and a $1 \mathrm{mg}$ subsample of each tissue was weighed in a tin cup, crushed and saved for SIA. Instruments were cleaned with acetone between samples to prevent crosscontamination. Isotope values were determined by the Stable Isotope Facility, University of California, Davis. Results are reported in delta notation $(\delta)$ in parts per thousand (\%) relative to air $\left(\delta^{15} \mathrm{~N}\right)$ and PeeDee Belemnite $\left(\delta^{13} \mathrm{C}\right)$. Replicate measurement of laboratory standards (2 standards for every 12 unknowns) indicated measurement errors of approximately 0.13 and $0.03 \%$ for nitrogen and carbon, respectively.
Discrimination factors: Isotope values of food fractionate when incorporated into consumer tissues. Such diet-tissue fractionation factors vary by species, tissue, nature and quality of the diet, nutritional status and other variables (reviewed by Vanderklift \& Ponsard 2003), and the choice of appropriate discrimination factors is vital. For adult puffins we used Cherel et al.'s (2005) average $( \pm$ SD) discrimination factors for adult fish-eating seabirds as follows: $+4.2 \pm 0.7 \%$ o $(\mathrm{n}=12)$ and $+2.7 \pm 0.4 \%$ o $(\mathrm{n}=4)$ for $\delta^{15} \mathrm{~N}$ and $+1.2 \pm 1.2 \%$ o $(\mathrm{n}=$ 6) and $0.0 \pm 0.8 \%$ o $(\mathrm{n}=4)$ for $\delta^{13} \mathrm{C}$, for feathers and blood, respectively. For first-year puffins, we adopted mean discrimination factors reported for 14 juvenile ring-billed gulls Larus delawarensis raised on a fish diet: $+3.0 \pm 0.2 \%$ and $+1.4 \pm 0.1 \%$ or $\delta^{15} \mathrm{~N}$ and $+0.2 \pm$ $1.3 \%$ and $+0.3 \pm 0.4 \%$ for $\delta^{13} \mathrm{C}$, for feathers and muscle, respectively (Hobson \& Clark 1992). To investigate seasonal and age-related variation in $\delta^{15} \mathrm{~N}$ and $\delta^{13} \mathrm{C}$, tissue stable isotope values were converted to estimated dietary intake values using appropriate diettissue discrimination factors prior to analysis.

Isotope mixing model: A 2-source single isotope $\left(\delta^{15} \mathrm{~N}\right)$ mixing model (Phillips \& Gregg 2001) was used to estimate contributions to puffin diets; sources were capelin and pelagic zooplankton (using values from Sherwood \& Rose 2005). Whole fish is depleted in $\delta^{15} \mathrm{~N}$ by $-0.9 \pm 0.1 \%$ and enriched in $\delta^{13} \mathrm{C}$ by $+0.3 \pm 0.1 \%$ relative to muscle alone (Cherel et al. 2005), and as seabirds eat whole fish, literature values for capelin muscle were adjusted prior to model application.

Stomach samples. When thawed, contents of the GI tracts were washed through a series of stacked sieves and placed in a sorting tray. For each sample, the presence/absence of broad prey classes (fish, cephalopods, crustaceans) was noted and, within each class, individual prey were counted and identified when possible using Härkönen (1986) and Campana (2004) for fish otoliths and Dunbar (1963) for crustaceans. The number of fish per sample was estimated from the highest count of either left- or right-hand side otoliths. When fish presence was noted from flesh or bones only, it was assumed to represent 1 individual. Fish body length was estimated from uneroded otolith dimensions (cf. Härkönen 1986). As only partial amphipods were recovered, numbers of individuals were estimated from the highest count of either heads or tails. Data are presented as percent frequency of occurrence and number, along with information on prey size.

At-sea distribution. Relative abundance of Atlantic puffins and other seabirds were quantified aboard vessels of opportunity operating within eastern Canadian continental shelf and Canadian Arctic waters under the Programme Intégré de Recherches sur les Oiseaux Pélagiques (PIROP, 1966-1992) and Eastern Canadian 
Seabirds at Sea (ECSAS, 2006-2009) programs. Under PIROP, all birds seen were counted during a 5 min observation period from a high location near the front of the ship, scanning either $90^{\circ}$ or $180^{\circ}$. The ECSAS program used a $90^{\circ}$ arc and introduced a $300 \mathrm{~m}$ transect width (also used on a small number of PIROP surveys during 1980s and 1990s). Position and time were recorded for each 5 (or 10) min period.

Data were compiled into a series of bins (15 min latitude $\times 15$ min longitude), each containing the total number of puffins counted and the total length of track $\left(\mathrm{km}\right.$, PIROP) or area of ocean surveyed $\left(\mathrm{km}^{2}\right.$, ECSAS), expressed as birds per linear $\mathrm{km}$ or $\mathrm{km}^{2}$, respectively. To provide a context for dietary information, distributional data were compiled for the spring-summer breeding period (May to mid-September) and for the fall (mid-September to November) and winter (December to April) periods. Separate maps were produced for adults, immatures and for all ages combined.

Analyses. Stable isotope data from feathers of 2 first-year puffins were excluded from analysis, as their $\delta^{15} \mathrm{~N}$ values (9.1 and 9.2\%) fell below average values measured for pelagic zooplankton in the region (9.9\%; Sherwood \& Rose 2005). These exceptionally low $\delta^{15} \mathrm{~N}$ values could reflect effects of growth or nutritional state on diet-feather fractionation (Williams et al. 2007, Sears et al. 2009); however, these processes are not well understood in growing birds. Isotope data derived from muscle tissue of these same individuals were within the expected range and were retained. Repeated measures techniques were used to examine the effects of season on isotope values for adult (winter versus summer) and first-year birds (summer versus fall), as these comparisons involved tissues from the same individuals, while the effects of age (adult, chick) on isotope values in summer were examined using independent measures techniques. Nonparametric tests were used when assumptions for the parametric tests were not met. Statistical tests were conducted using Systat for Windows (v.10.2). Values are presented as means $\pm \mathrm{SD}$, and an alpha level of 0.05 was adopted to indicate statistical significance.

\section{RESULTS}

\section{Stable isotope analysis}

Mean measured $\delta^{15} \mathrm{~N}$ values (i.e. without correction for discrimination factors) ranged from $12.2 \pm 0.7 \%$ in pectoral muscle of first-year birds in fall to $14.3 \pm 0.3 \%$ in adult whole blood in summer (Table 1). Mean measured $\delta^{13} \mathrm{C}$ values ranged from $-19.0 \pm 0.2 \%$ in pectoral muscle of first-year birds in fall to $-17.7 \pm 0.5 \%$ in adult feathers grown in winter (Table 1). Isotope values were corrected by appropriate discrimination factors prior to statistical analysis.

For adults, $\delta^{15} \mathrm{~N}$ values increased significantly between the winter (moulting) and summer (breeding) periods (Wilcoxon signed-ranks test: $Z_{28}=4.53, \mathrm{p}<$ 0.001 ; Fig. 2). The mean $2.36 \% \delta^{15} \mathrm{~N}$ increase corresponds to $0.65 \mathrm{TL}$, using an isotopic enrichment factor of $3.6 \%$ between adjacent TLs calculated by Fry (1988) for the George's Bank region, and was associated with a parallel decrease in $\delta^{15} \mathrm{~N}$ variability (Table 1, Fig. 2).

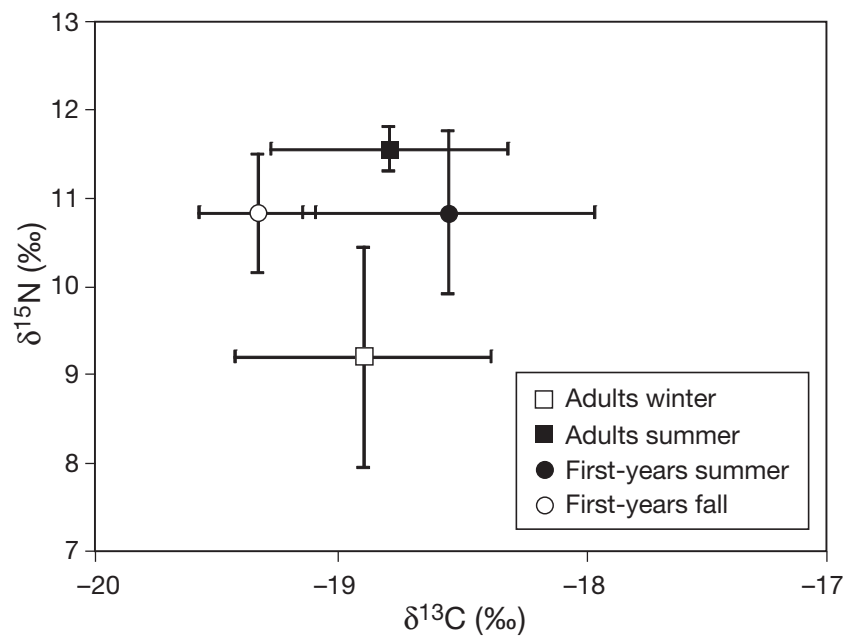

Fig. 2. Fratercula arctica. Mean $( \pm \mathrm{SD}) \delta^{15} \mathrm{~N}$ and $\delta^{13} \mathrm{C}$ values in puffin tissues, after correction for diet-tissue isotopic discrimination. The following discrimination factors were applied for $\delta^{15} \mathrm{~N}$ and $\delta^{13} \mathrm{C}$, respectively: adult feathers (winter) $+4.2 \pm 0.7 \%$ and $+1.2 \pm 1.2 \%$, and blood (summer) $+2.7 \pm 0.4 \%$ and $0.0 \pm 0.8 \%$; first-year feathers (summer) $+3.0 \pm 0.2 \%$ ond $+0.2 \pm 1.3 \%$, and first-year muscle (fall) $+1.4 \pm 0.1 \%$ and $+0.3 \pm 0.4 \%$

Table 1. Fratercula arctica. Mean $( \pm \mathrm{SD})$ uncorrected values of stable nitrogen $\left(\delta^{15} \mathrm{~N}\right)$ and carbon $\left(\delta^{13} \mathrm{C}\right)$ isotopes from blood, muscle and feather samples of adult and first-year Atlantic puffins, Newfoundland, 2004-2005

\begin{tabular}{|llccrrr|}
\hline Collection site, month and year & \multirow{2}{*}{ Age class } & Tissue & Season & $\mathrm{n}$ & $\delta^{15} \mathrm{~N}(\%)$ & $\delta^{13} \mathrm{C}(\%)$ \\
\hline Gull Island, Witless Bay, July 2005 & Adult & Feather & Winter (moulting) & 28 & $13.4 \pm 1.3$ & $-17.7 \pm 0.5$ \\
& Adult & Blood & Summer (breeding) & 28 & $14.3 \pm 0.3$ & $-18.8 \pm 0.5$ \\
Bay of Exploits, October 2004 & First-year & Feather & Summer (chick) & 9 & $13.9 \pm 0.9$ & $-18.4 \pm 0.6$ \\
& First-year & Muscle & Fall (independent) & 10 & $12.2 \pm 0.7$ & $-19.0 \pm 0.2$ \\
& & & &
\end{tabular}


Mixing model results (Table 2) suggest that adults consume largely zooplankton or other lower TL prey during winter with a switch to capelin or other higher TL prey in summer. $\delta^{13} \mathrm{C}$ values for adults were similar in winter and summer (repeated-measures ANOVA: $F_{1,27}=$ $0.74, \mathrm{p}>0.39$ ).

For first-year birds, $\delta^{15} \mathrm{~N}$ values were indistinguishable when chicks were being fed by parents in summer and when they were subsequently self-feeding in fall (repeated-measures ANOVA: $F_{1,7}=$ $0.64, p>0.45$; Fig. 2). The average seasonal difference in $\delta^{15} \mathrm{~N}$ values was only $0.01 \%$. Mixing model results suggest that offspring were provisioned with $\sim 68 \%$ capelin (or other higher TL prey) and $32 \%$ zooplankton (or other lower TL prey) during the rearing period, and that the diet was largely similar in fall (Table 2). $\delta^{13} \mathrm{C}$ values of the first-year birds declined from summer to fall (Wilcoxon signed-ranks test: $Z_{9}=2.38, \mathrm{p}<$ 0.05).

In summer, adults had significantly higher $\delta^{15} \mathrm{~N}$ values than first-year birds (Mann-Whitney $U$-test: $U=196, \mathrm{p}<0.05$ ) but similar values for $\delta^{13} \mathrm{C}$ (1-way ANOVA: $F_{1,35}=1.50, p>0.20 ;$ Fig. 2 ). The mean $\delta^{15} \mathrm{~N}$ difference was $0.72 \%$ ( $\left.0.2 \mathrm{TL}\right)$.

\section{Stomach contents of first-year puffins}

First-year (self-feeding) puffins consumed both crustaceans (occurrence $=80 \%$ ) and fish (occurrence $=$ $60 \%$; Table 3$) ; 40 \%(\mathrm{n}=4)$ of stomachs contained only crustaceans, $20 \%(\mathrm{n}=2)$ contained only fish, and the remaining stomachs $(40 \%, \mathrm{n}=4)$ contained a mix of these prey types. Overall, 42 prey items were recovered and, while dominated by crustaceans in number $(83 \%)$, the calculated size of fish recovered indicated that fish represented the bulk of mass (and likely energy). Crustaceans included 3 hyperiid amphipods: Hyperia medusarum, Hyperoche medusarum and Themisto libellula (occurring most frequently; Table 3). Mature capelin (137 $\pm 4.6 \mathrm{~mm}, \mathrm{n}=3)$ and unidentifiable fish remains each occurred in $30 \%$ of stomachs.

\section{Distribution of birds at sea}

Visual inspection of the seasonal maps for adults and immatures showed no distributional differences, thus
Table 2. Fratercula arctica. Seasonal diet composition of adult and first-year Atlantic puffins in Newfoundland, 2004-2005, estimated using the 2-source $\&$ Gregg (2001). Data are means \pm SE (95\% confidence intervals)

Table 3. Fratercula arctica. Stomach contents of 10 first-year Atlantic puffins ot on 23 October 2004, expressed as percent frequency of occurrence (\% of

\begin{tabular}{|c|c|c|c|c|c|c|}
\hline \multirow[t]{2}{*}{ Prey species } & \multirow{2}{*}{$\begin{array}{c}\text { Dccurrence } \\
\%\end{array}$} & \multicolumn{2}{|c|}{ Number } & \multicolumn{3}{|c|}{ Body length (mm) } \\
\hline & & $\mathrm{n}$ & $\%$ & Mean $\pm \mathrm{SD}$ & Range & $\mathrm{n}$ \\
\hline Fish & 60 & 7 & 16.7 & & & \\
\hline \multicolumn{7}{|l|}{ Osmeridae } \\
\hline Mallotus villosus & 30 & 4 & 9.5 & $137 \pm 4.6$ & $131-142$ & 3 \\
\hline Unidentifiable/digested fish & 30 & 3 & 7.1 & & & \\
\hline Crustaceans & 80 & 35 & 83.3 & & & \\
\hline \multicolumn{7}{|l|}{ Amphipoda } \\
\hline Hyperia medusarum & 10 & 1 & 2.4 & & & \\
\hline Hyperoche medusarum & 20 & 2 & 4.8 & & & \\
\hline Themisto libellula & 50 & 9 & 21.4 & & & \\
\hline Themisto sp. & 40 & 12 & 28.6 & & & \\
\hline Unidentified hyperiids & 50 & 11 & 26.2 & & & \\
\hline
\end{tabular}

only one set of maps is presented with the age classes combined (Fig. 3). The at-sea distribution of puffins from PIROP (1966-1992) and ECSAS (2006-2009) data sets showed roughly similar patterns in all seasons. During the breeding period (May to mid-September), puffins were concentrated to the north and east of eastern Newfoundland and along the southeast coast of Labrador in proximity to their largest breeding colonies, with smaller numbers observed further offshore over the continental shelf (Fig. 3A,D). During fall (mid-September to November), birds were distributed more evenly across the shelf and beyond into deeper $(>1000 \mathrm{~m})$ waters, although there were still considerable clusters along the coast of southern Labrador and off northeast Newfoundland (Fig. 3B,E). Birds were also distributed further south in fall, with more birds observed on the Scotian Shelf in recent survey years (ECSAS). During winter (December to April), puffins showed a more even east-west cross-shelf distribution, with few birds being found very close to the coastline (Fig. 3C,F). Birds shifted even further south in winter with increasing numbers observed on the Scotian Shelf and few observed north of the eastern Newfoundland coast. By late winter, birds again began to concentrate in the vicinity of their eastern Newfoundland breeding colonies. 

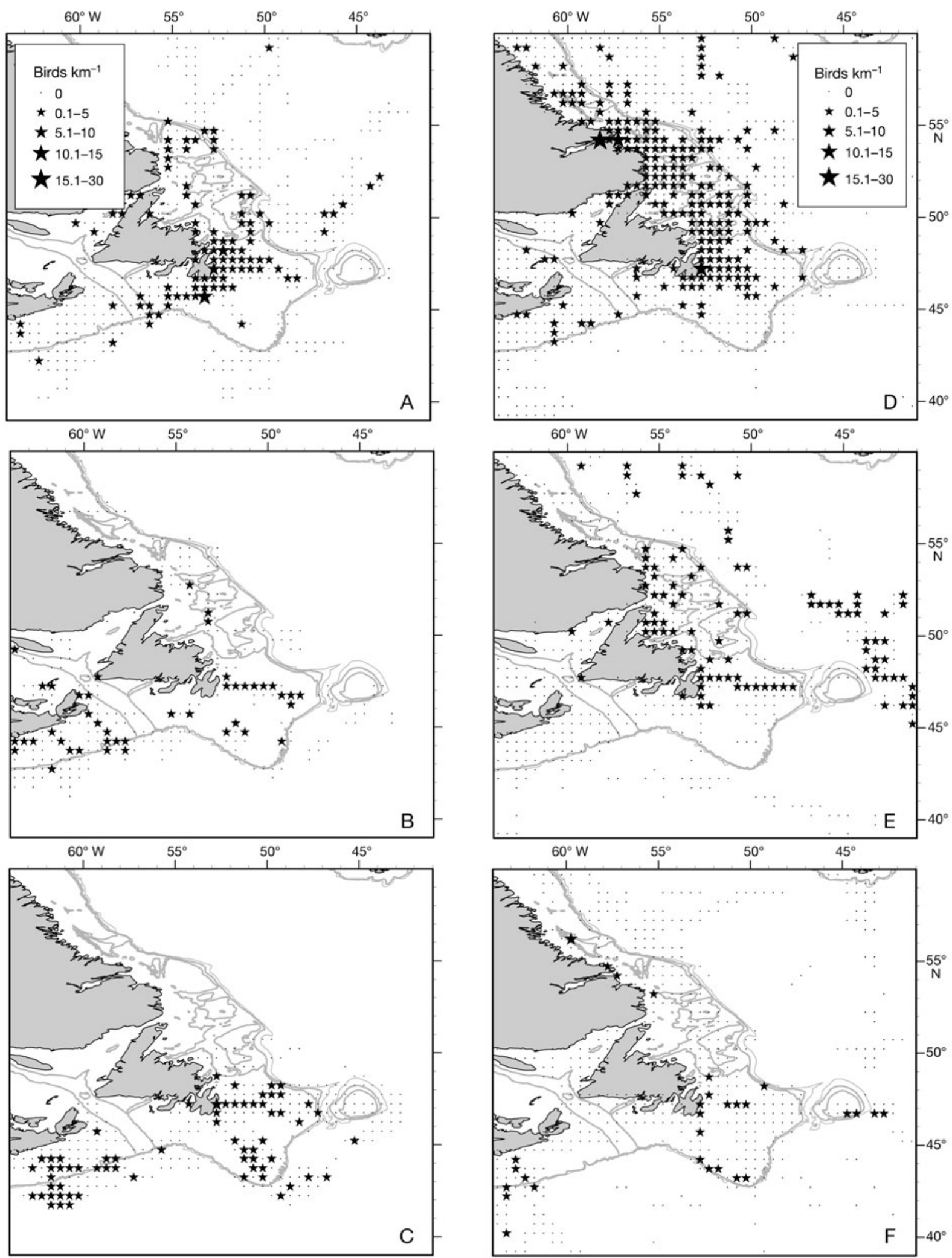

Fig. 3. Fratercula arctica. At-sea distribution of Atlanfic puffins from the Eastern Canadian Seabirds at Sea (ECSAS, left column) and Programme Intégré de Recherches sur les Oiseaux Pélagiques (PIROP, right column) databases during: (A,D) the breeding period, May to mid-September; $(B, E)$ fall, mid-September to November; and $(C, F)$ winter, December to April 


\section{DISCUSSION}

\section{Adult foraging ecology: seasonal variation in trophic niche}

Using SIA, we observed a seasonal shift and a narrowing of the trophic niche of adult puffins, suggesting a transition from a generalized diet incorporating zooplankton and other lower TL prey in winter to a highly specialized, higher TL diet during summer. This shift in foraging strategy might be related to seasonal fluctuations in prey abundance and/or differential energetic constraints during the summer breeding (selfand offspring provisioning) and winter non-breeding (self-provisioning) periods.

Reliance of adult Atlantic puffins on a specialized, high TL diet during breeding is consistent with available information from Witless Bay. Adults consumed fish, largely capelin, during the breeding season and also fed their offspring almost exclusively on capelin (Piatt 1987, Nettleship 1991, Rodway \& Montevecchi 1996, Baillie \& Jones 2003). Capelin is an abundant, energetically rich forage fish (Montevecchi \& Piatt 1984) that has a predictable coastal distribution in Newfoundland during the summer, and peak availability (July) coincides with the breeding period of seabirds (Davoren \& Montevecchi 2003). Historically, the spawning biomass of capelin has been very high in Witless Bay and throughout the 1990s; when capelin abundance declined in many areas, biomass estimates for Witless Bay remained high (Carscadden 1984, Carscadden \& Nakashima 1997). Given the local abundance of a nutritious and predictable food source, it is clearly advantageous for adult puffins at Gull Island to specialize on capelin during the breeding season.

In contrast, SIA of feathers grown during the moulting period indicates that in winter adults likely consume a wide range of lower TL prey. Widening the trophic niche in winter appears to be a viable strategy for adults when they are released from the constraints associated with central place foraging and can adopt a more free-ranging and opportunistic foraging strategy (Cherel et al. 2007). This strategy enables the auks to meet nutritive requirements during the costly moulting period (Thompson \& Kitaysky 2004), despite the lost access to energy-rich capelin which migrate into deeper waters in winter (Templeman 1948, Mowbray 2002) and become inaccessible to Atlantic puffins that cannot dive beyond 41 to 68 m (Burger \& Simpson 1986).

There are no other data on winter diets of Northwest Atlantic puffins, though information from the Northeast Atlantic suggests strong regional variation (Falk et al. 1992). Offshore puffins in the Norwegian Sea largely consumed glacier lanternfish Benthosema glaciale and squid Gonatus fabricii in winter, whereas inshore puffins, near the Faroe Islands, consumed euphausiid crustaceans and fish (largely sandlance; Falk et al. 1992). Overall, fish were the most important prey in the Northeast Atlantic. Though we used pelagic zooplankton to represent the lower TL dietary component in our mixing models, inclusion of other taxa could have generated the observed range of $\delta^{15} \mathrm{~N}$ values for adult puffins, including a variety of lower TL fish, such as lanternfish and sandlance (Sherwood \& Rose 2005, Hedd \& Montevecchi 2006), known to be important components of diets for locally breeding Leach's stormpetrels Oceanodroma leucorhoa (Hedd et al. 2009).

Recent studies suggest substantial species differences in the nature and extent of seasonal (stage to stage) variation in the foraging ecology of auks (Moody \& Hobson 2007, Williams et al. 2008, Davies et al. 2009). For example, within the community at Triangle Island, British Columbia, only the puffins (tufted puffin Fratercula cirrhata and rhinoceros auklet Cerorhinca monocerata) exhibited an upward seasonal shift, with a lower TL diet during pre-laying being replaced by a higher TL diet during chick-rearing (Davies et al. 2009). Other auks fed at similar (common murre Uria aalge and pigeon guillemot Cepphus columba) or lower (Cassin's auklet Ptychoramphus aleuticus) TLs across the same periods. Tufted puffins in Alaska exhibited a trend similar to those breeding in British Columbia, increasing by 0.47 to 0.68 TLs across the season (Williams et al. 2008). In combination with our data for Atlantic puffins, where TL increased by 0.65 from mid-winter to chick-rearing, we hypothesize that a seasonal increase in TL feeding may be the norm for puffin species.

One potential bias for quantifying the extent of the seasonal TL shift of Atlantic puffins arises from Sherwood \& Rose's (2005) finding that $\delta^{15} \mathrm{~N}$ signatures of fish and invertebrates in nearshore Newfoundland habitats were significantly higher than those at the shelf edge. If puffins coincidentally shift from foraging nearshore in summer to offshore in winter, a parallel within-prey change in $\delta^{15} \mathrm{~N}$ could explain some of what otherwise appears to be a trophic shift. While the highly mobile nature of pelagic seabirds would likely act to reduce this bias (birds could potentially forage nearshore or offshore at any time), resolving its magnitude would require contemporaneous information on movements of individual birds which, unfortunately, is lacking.

\section{First-year birds: similar trophic niche in summer and fall}

The trophic position of first-year birds in fall was similar to that measured when birds were being fed by their parents in the burrow in summer. Diet composi- 
tion was approximately two-thirds capelin (or other higher TL prey) and one-third zooplankton (or other lower TL prey) in summer, with the higher TL component making a slightly greater contribution in fall. Our model estimates accord well with available information. In the Northwest Atlantic, puffins rely strongly on fish, particularly capelin and sandlance, for chick provisioning (Piatt 1987, Burke \& Montevecchi 2008), but diets do show significant variation among colonies (Russell 1999, Baillie \& Jones 2003) and years (Burke \& Montevecchi 2008). Larval fish and invertebrates can form key components of summer chick diets, but their importance can diminish with the availability of higher quality prey near the colony (Burke 2008) and/or with increasing chick requirements (Burke \& Montevecchi 2008). The degree of variability observed in $\delta^{15} \mathrm{~N}$ signatures suggests that in the present study chicks were provisioned with a mixed diet when their primary feathers emerged at $\sim 20$ to $30 \mathrm{~d}$ (Lowther et al. 2002).

Stomach contents analysis agreed with synoptic SIA of the pectoral muscle, indicating that when self-feeding first-year birds fed on a variety of fish and crustacean species. First-year puffins may feed opportunistically on passive prey in the water column (larval fish, zooplankton) as well as on larger capelin that are presumably available nearshore in fall. Dietary breadth when self-feeding was similar to that when the primary feathers emerged, again indicating a mixed diet.

\section{Adult versus chick diets in summer}

In summer adults had a significantly higher TL (0.2) than chicks and their diets were more specialized. However, many physiological and methodological factors complicate this comparison. As adult and chick samples were collected in different years, betweenyear differences in isotopic signatures of prey could also contribute to variation in puffin tissues (Williams et al. 2008). Reduced food intake during growth has been shown to reduce $\delta^{15} \mathrm{~N}$ values in other puffin species (Williams et al. 2007, Sears et al. 2009). Also, we did not compare adult diet to the diet of the chicks they were provisioning and, due to the colony-specific (Russell 1999, Baillie \& Jones 2003) and interannual (Rodway \& Montevecchi 1996, Burke \& Montevecchi 2008) variability characteristic of puffin chick diets, the results must be interpreted with caution.

\section{Seasonal change in at-sea distribution of Atlantic puffins}

Atlantic puffins in the Northwest Atlantic are distributed largely inshore in close proximity to the breeding colonies in summer (Brown 1986, Lowther et al. 2002; Fig. 3A, D). Winter distribution and migration in the Northwest Atlantic is poorly understood, but information from vessel surveys (Brown 1986; Fig. 3) indicates a movement offshore with birds wintering in southern Labrador, through the Newfoundland Grand Bank south to the Scotian Shelf. Despite this distributional shift, we detected no difference in $\delta^{13} \mathrm{C}$ signatures of adults from summer to winter. For first-year birds, significantly enriched $\delta^{13} \mathrm{C}$ values in summer likely reflect the predominately inshore foraging distribution of provisioning adults when they are limited by central place foraging constraints (Burke \& Montevecchi 2008). Decreasing $\delta^{13} \mathrm{C}$ values of first-year birds in fall suggests dispersal away from inshore colonies; however, the fact that birds were shot by hunters demonstrates that they were inshore when killed. In contrast to Hobson et al. (1994), who found a strong inshore-offshore gradient in tissues of Pacific auks, overall, $\delta^{13} \mathrm{C}$ values added little to our understanding of seasonal variation in distribution of Atlantic puffins. However, isotopic comparison of adults, juveniles and nestlings is a valuable technique for understanding the changing dietary status of these birds, which is much more difficult to assess directly. Research focused on filling the winter data gap-particularly studies linking movement (Harris et al. 2010) and dietary patterns of individual birds - needs to be pursued.

Acknowledgements. We are grateful to C. Baker, K. Lewis and S. Bin Muzzafar for help in the field and to P. Mallam for expert assistance in the lab preparing samples for isotope analysis and sorting through the puffin stomachs. We are also grateful to the Newfoundland and Labrador Parks Division for granting a research access permit to Gull Island in the Witless Bay Provincial Seabird Ecological Reserve. This research was supported by a National Sciences and Engineering Research Council Discovery Grant and the Government of Canada's Program for International Polar Year to W.A.M., and by support to G.J.R. from Environment Canada through the Environmental Studies Research Fund.

\section{LITERATURE CITED}

Anker-Nilssen T (1987) The breeding performance of puffins Fratercula arctica on Røst, northern Norway in 1979-1985. Fauna Nor C 10:21-38

Baillie SM, Jones IL (2003) Atlantic puffin (Fratercula arctica) chick diet and reproductive performance at colonies with high and low capelin (Mallotus villosus) abundance. Can J Zool 81:1598-1607

Baillie SM, Jones IL (2004) Response of Atlantic puffins to a decline in capelin abundance at the Gannet Islands, Labrador. Waterbirds 27:102-111

Barrett RT, Camphuysen CJ, Anker-Nilssen T, Chardine JW and others (2007) Diet studies of seabirds: a review and recommendations. ICES J Mar Sci 64:1675-1691

> Bearhop S, Waldron S, Votier S, Furness RW (2002) Factors that influence assimilation rates and fractionation of nitro- 
gen and carbon stable isotopes in avian blood and feathers. Physiol Biochem Zool 75:451-458

Bradstreet MSW, Brown RGB (1985) Feeding ecology of the Atlantic Alcidae. In: Nettleship DN, Birkhead TR (eds) The Atlantic Alcidae: evolution, distribution and biology of the auks inhabiting the Atlantic Ocean and adjacent water areas. Academic Press, London, p 264-318

Brown RGB (1986) Revised atlas of eastern Canadian seabirds. Shipboard surveys. Government Publishing Centre, Ottawa, Ontario

Burger AE, Simpson M (1986) Diving depths of Atlantic puffins and common murres. Auk 103:828-830

Burke CM (2008) Comparative foraging ecology of parental common murres (Uria aalge) and Atlantic puffins (Fratercula arctica) in response to changes in forage fish availability. MS thesis, Memorial University, St. John's, Newfoundland

Burke CM, Montevecchi WA (2008) Fish and chicks: forage fish and chick success in co-existing auks. Waterbirds 31:372-384

Campana SE (2004) Photographic atlas of fish otoliths of the Northwest Atlantic. Can Spec Publ Fish Aquat Sci 133: $1-284$

Carscadden JE (1984) Capelin in the Northwest Atlantic. In: Nettleship DA, Sanger GA, Springer PF (eds) Marine birds: their feeding ecology and commercial fisheries relationships. Can Wildl Serv Spec Pub, Proc Pac Seabird Grp Symp, Seattle, WA, p 170-183

Carscadden JE, Nakashima BS (1997) Abundance and changes in distribution, biology and behaviour of capelin in response to cooler waters of the 1990s. In: Forage fishes in marine ecosystems. Proc Int Symp on the Role of Forage Fishes in Marine Ecosystems. AK-SG-97-01, Anchorage, AK, p 457-468

Cherel Y, Hobson KA (2007) Geographical variation in carbon stable isotope signatures of marine predators: a tool to investigate their foraging areas in the Southern Ocean. Mar Ecol Prog Ser 329:281-287

- Cherel Y, Hobson KA, Weimerskirch H (2000) Using stableisotope analysis of feathers to distinguish moulting and breeding origins of seabirds. Oecologia 122:155-162

Cherel Y, Hobson KA, Hassani S (2005) Isotopic discrimination between food and blood and feathers of captive penguins: implications for dietary studies in the wild. Physiol Biochem Zool 78:106-115

> Cherel Y, Phillips RA, Hobson KA, McGill R (2006) Stable isotope evidence of diverse species-specific and individual wintering strategies in seabirds. Biol Lett 2:301-303

Cherel Y, Hobson KA, Guinet C, Vanpe C (2007) Stable isotopes document seasonal changes in trophic niches and winter foraging: individual specialization in diving predators from the Southern Ocean. J Anim Ecol 76:826-836

Davies WE, Hipfner JM, Hobson KA, Ydenberg RC (2009) Seabird seasonal trophodynamics: isotopic patterns in a community of Pacific alcids. Mar Ecol Prog Ser 382: 211-219

> Davoren GK, Montevecchi WA (2003) Signals from seabirds indicate changing biology of capelin stocks. Mar Ecol Prog Ser 258:253-261

Dunbar MJ (1963) Fiches d'identification du zooplancton, No. 103. Counseil International pour l'explorations de la mer, Copenhagen

Einoder LD (2009) A review of the use of seabirds as indicators in fisheries and ecosystem management. Fish Res 95:6-13

Falk K, Jensen JK, Kampp K (1992) Winter diet of Atlantic puffins (Fratercula arctica) in the Northeast Atlantic. Colon Waterbirds 15:230-235
Fry B (1988) Food web structure on Georges Bank from stable $\mathrm{C}, \mathrm{N}$ and $\mathrm{S}$ isotopic compositions. Limnol Oceanogr 33: $1182-1190$

Gaston AJ, Jones IL (1998) The auks. Oxford University Press, Oxford

Härkönen T (1986) Guide to the otoliths of the bony fishes of the Northeast Atlantic. Danbiu, Copenhagen

Harris MP (1979) Measurements and weights of British puffins. Bird Study 26:179-186

Harris MP (1984) The puffin. T \& AD Poyser, Calton

> Harris MP, Yule RF (1977) The moult of the puffin Fratercula arctica. Ibis 119:535-541

Harris MP, Daunt F, Newell M, Phillips RA, Wanless S (2010) Wintering areas of adult Atlantic puffins Fratercula arctica from a North Sea colony as revealed by geolocation technology. Mar Biol 157:827-836

Hedd A, Montevecchi WA (2006) Diet and trophic position of Leach's storm-petrel Oceanodroma leucorhoa during breeding and moult, inferred from stable isotope analysis of feathers. Mar Ecol Prog Ser 322:291-301

Hedd A, Montevecchi WA, Davoren G, Fifield DA (2009) Diets and distributions of Leach's storm-petrel Oceanodroma leucorhoa before and after an ecosystem shift in the Northwest Atlantic. Can J Zool 87:787-801

> Hobson KA (1993) Trophic relationships among high Arctic seabirds: insights from tissue-dependent stable-isotope models. Mar Ecol Prog Ser 95:7-18

> Hobson KA, Clark RG (1992) Assessing avian diets using stable isotopes II: factors influencing diet-tissue fractionation. Condor 94:189-197

Hobson KA, Piatt JF, Pitocchelli J (1994) Using stable isotopes to determine seabird trophic relationships. J Anim Ecol 63:786-798

> Hobson KA, Gibbs HL, Gloutney ML (1997) Preservation of blood and tissue samples for stable-carbon and stablenitrogen isotope analysis. Can J Zool 75:1720-1723

Hobson KA, Fisk A, Karnovsky N, Holst M, Gagnon JM, Fortier M (2002) A stable isotope $\left(\delta^{13} \mathrm{C}, \delta^{15} \mathrm{~N}\right)$ model for the North Water food web: implications for evaluating trophodynamics and the flow of energy and contaminants. DeepSea Res II 49:5131-5150

Hodum PJ, Hobson KA (2000) Trophic relationships among Antarctic fulmarine petrels: insights into dietary overlap and chick provisioning strategies inferred from stableisotope $\left(\delta^{15} \mathrm{~N}\right.$ and $\left.\delta^{13} \mathrm{C}\right)$ analyses. Mar Ecol Prog Ser 198: 273-281

Lowther PE, Diamond AW, Kress SW, Robertson GJ, Russell K (2002) Atlantic puffin Fratercula arctica. In: Poole A (ed) The birds of North America online. Ithaca: Cornell Lab of Ornithology, http://bna.birds.cornell.edu/bna/species/709

Mizutani H, Fukuda M, Kabaya Y (1992) ${ }^{13} \mathrm{C}$ and ${ }^{15} \mathrm{~N}$ enrichment factors of feathers of 11 species of adult birds. Ecology 73:1391-1395

> Montevecchi WA, Piatt JF (1984) Composition and energy content of mature inshore spawning capelin (Mallotus villosus): implications for seabird predators. Comp Biochem Physiol A 78:15-20

Moody AT, Hobson KA (2007) Alcid winter diet in the Northwest Atlantic determined by stable isotope analysis. Mar Ornithol 35:39-46

> Mowbray FK (2002) Changes in the vertical distribution of capelin (Mallotus villosus) off Newfoundland. ICES J Mar Sci 59:942-949

Nettleship DN (1991) The diet of Atlantic puffin chicks in Newfoundland before and after initiation of an international capelin fishery, 1967-1984. Proc 20th Int Ornithol Congr 20:2263-2271 
Petersen A (1976) Size variables in puffins Fratercula arctica from Iceland, and bill features as criteria of age. Ornis Scand 7:185-192

Phillips DL, Gregg JW (2001) Uncertainty in source partitioning using stable isotopes. Oecologia 127:171-179

Phillips RA, Bearhop S, McGill RAR, Dawson DA (2009) Stable isotopes reveal individual variation in migration strategies and habitat preferences in a suite of seabirds during the nonbreeding season. Oecologia 160:795-806

Piatt JF (1987) Behavioral ecology of common murre and Atlantic puffin predation on capelin: implications for population biology. PhD thesis, Memorial University, St. John's, Newfoundland

Quillfeldt P, McGill RAR, Furness RW (2005) Diet and foraging areas of Southern Ocean seabirds and their prey inferred from stable isotopes: review and case study of Wilson's storm-petrel. Mar Ecol Prog Ser 295:295-304

Robertson GJ, Wilhelm SI, Taylor PA (2004) Population size and trends of seabirds breeding on Gull and Great Islands, Witless Bay Islands Ecological Reserve, Newfoundland, up to 2003. Can Wildl Serv Tech Rep Ser No. 418

Robinette DP, Howar J, Sydeman WJ, Nur N (2007) Spatial patterns of recruitment in a demersal fish as revealed by seabird diet. Mar Ecol Prog Ser 352:259-268

Rodway MS, Montevecchi WA (1996) Sampling methods for assessing the diets of Atlantic puffin chicks. Mar Ecol Prog Ser 144:41-55

Russell J (1999) Chick diet and nestling condition among Atlantic puffins at three Northwest Atlantic colonies. MS thesis, Memorial University, St. John's, Newfoundland

Editorial responsibility: William Sydeman,

Petaluma, California, USA
Sears J, Hatch SA, O'Brien DM (2009) Disentangling effects of growth and nutritional status on seabird stable isotope ratios. Oecologia 159:41-48

Sherwood GD, Rose GA (2005) Stable isotope analysis of some representative fish and invertebrates of the Newfoundland and Labrador continental shelf food web. Estuar Coast Shelf Sci 63:537-549

Sorensen MC, Hipfner JM, Kyser TK, Norris DR (2009) Carryover effects in a Pacific seabird: stable isotope evidence that pre-breeding diet quality influences reproductive success. J Anim Ecol 78:460-467

Templeman W (1948) The life cycle of capelin (Mallosus villosus) in Newfoundland waters. Bull Nfld Gov 17:1-151

> Thompson CW, Kitaysky AS (2004) Polymorphic flightfeather molt in tufted puffins (Fratercula cirrhata): a rare phenomenon in birds. Auk 121:35-45

Vanderklift MA, Ponsard S (2003) Sources of variation in consumer-diet $\delta^{15} \mathrm{~N}$ enrichments: a meta-analysis. Oecologia 136:169-182

> Williams CT, Buck CL, Sears J, Kitaysky AS (2007) Effects of nutritional restriction on nitrogen and carbon stable isotopes in growing seabirds. Oecologia 153:11-18

Williams CT, Iverson SJ, Buck CL (2008) Stable isotopes and fatty acid signatures reveal age- and stage-dependent foraging niches in tufted puffins. Mar Ecol Prog Ser 363: $287-298$

> Yerkes T, Hobson KA, Wassenaar LI, Macleod R, Coluccy JM (2008) Stable isotopes $\left(\delta \mathrm{D}, \delta^{13} \mathrm{C}, \delta^{15} \mathrm{~N}\right)$ reveal associations among geographic location and condition of Alaskan northern pintails. J Wildl Manag 72:715-725

Submitted: September 18, 2009; Accepted: January 22, 2010 Proofs received from author(s): March 5, 2010 